\title{
Development of Guided Inquiry Based Teaching Materials Enriched with Augmented Reality
}

\author{
Venin Kharisma Noviantia ${ }^{\text {a }}$, Munzil ${ }^{\text {b, } * \text {, Vita Ria Mustikasari }}{ }^{\text {c }}$, Erni Yulianti ${ }^{\text {d }}$ \\ a,b,c,d Study Program of Science Education, Universitas Negeri Malang, \\ Malang, East Java, Indonesia \\ *Corresponding author's e-mail: munzil.fmipa@um.ac.id
}

\begin{abstract}
The purpose of this research and development is to produce Guided-Inquiry Based Teaching Materials Enriched by Augmented Reality (AR) on the subject of light and optics for 8th grade which is feasible and valid, as a teaching materials during the COVID-19 pandemic. This research and development using Lee and Owen's method. However, it was narrowed down into 3 stages only, which are : assessment/analysis, design, and development stage. The teaching material's validity was obtained from expert's validation result, while the feasibility was obtained from the feasibility test on the students. Developed teaching materials takes form of an A5 sized pocket book, and discuss about the basic competencies in the subject of light and optics. Subject delivery served through learning module, learning video, and AR technology on image formation as well as using Google Form as student worksheet. The validation result shows that developed teaching materials are feasible and valid with score percentage $>61 \%$.
\end{abstract}

\section{Introduction}

The essence of Science in learning covers three main and inseparable element, which are attitude, process, and product. Science learning is not only about students receiving information from the teacher, but students also have to be given live-experience in teaching and learning activities to optimizing student's knowledge and concept of science [1]. Science Learning has to emphasize on scientific approach along with approach on learning-experience which are observing, asking, collecting information, associating, and communicating. Guided Inquiry is one of the suitable learning model for scientific approach because it can integrate science skill entirely. Using guided inquiry, the students have the chance to formulate problem procedure, analyze experimental results and making conclusion independently, so that the teacher served as facilitator to choose the topic, question and the other supporting material [2]. 
Supporting component in implementing guided inquiry is a teaching material. Teaching material used as learning resources for students in order to learn independently which contain a set of learning subject. The use of a suitable teaching material can assist the process of constructing a concept easily on the students. The existing teaching materials tend to be monotone and uninteresting. Moreover, most teaching material don't use a suitable learning strategy so that the students have difficulty in learning and understanding science subject. In science learning, the students are required to understand the theory, concept, law, and principles meaningfully, so they can apply it in explaining related phenomenon [3]. Science learning demands the students to learn the life between living things and their natural surroundings and its application in ecosystem [4].

One of the science subject in middle school level is light and optics. The students are able to understand the phenomenon that occurs in daily life related to lights and technology which was created based on reflection and refraction, image formation on human's eyes and the disorders, and image formation on optical devices [5].

The existing teaching materials used in school tend to be boring, only theoretical, and takes form of text so it doesn't really catch student's interest [6]. Moreover, the teaching materials used in school don't be combined with the learning model that suitable with student's character, making it ineffective if used in learning. Usage of a suitable method and the right teaching materials in integrated science learning in necessary to solve student's problem in learning, especially in the subject of light and optics [3]. The teaching materials are expected to attract student's interest to learn so it leads to focus on learning, and one of the ways is by using teaching materials combined with technology [7].

Augmented Reality (AR) is one of the technology that can be developed. AR technology is a technology that can combine virtual image $2 \mathrm{D}$ or $3 \mathrm{D}$ with real world more interactively [6]. AR can make it easier for students to understand the theory and concept and stimulate to think conceptually in interactive and delightful learning [7]. In current educational world, there are many research and development about augmented reality (AR) technology because it has advantages in terms of realistically portray the abstract concepts in science so the students are able to understand more clearly. However, the usage and development of augmented reality-based books hasn't been found much in middle school science. Moreover, using technology in education during Covid-19 in Indonesia is in accordance with circular letter No. 4 by the Minister of Education and Culture in 2020, stating that learning process in done from home can give meaningful experience for students with online learning [8]. 


\section{Method}

Write the method here write the method here write the method here write the method here write the method here write the method here write the method here write the method here write the method here write the method here write the method here. This research and development using Lee \& Owens development model. The sequence of Lee \& Owens's development model are assessment/analysis, includes need assessment and front-end analysis, design, development, implementation, evaluation [9]. Design of Lee \& Owens's development model can be seen in Lee and Owens' design of development model below as Figure 1.

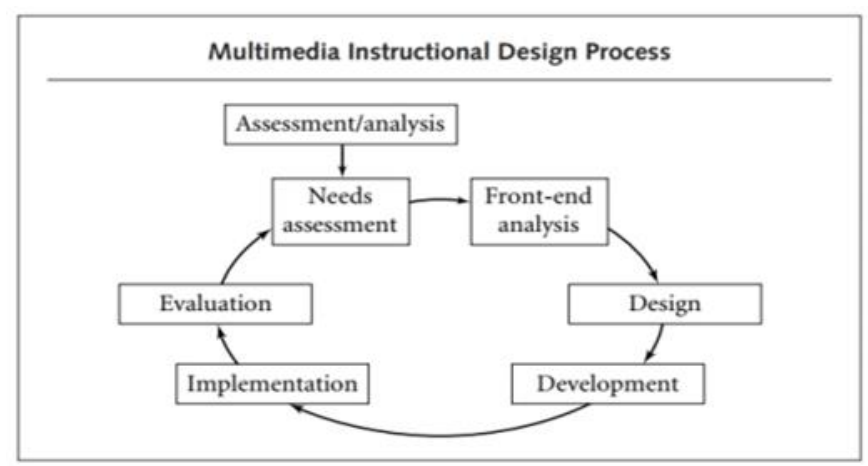

Figure 1. Development Procedure Model

Source: (Lee \& Owens, 2004)

This research and development only up to the first 3 stages, which are assessment/analysis, includes need assessment and front-end analysis, design, development. The instrument used in this research and development is questionnaire made in Google Form. Validity and feasibility assessment is done through validation by lecturer as validator and teacher as the experts on the subject and media. Validation result came as quantitative and qualitative data.

\section{Results}

The developed teaching materials is guided inquiry based enriched by augmented reality technology in the subject of light and optics accorded to Basic Competencies 3.9 and 4.9 K13 8th grade middle school. This teaching material takes form of pocket book in the size $14.8 \mathrm{~cm} \times 21$ $\mathrm{cm}$ (A5). In this teaching material, learning activity focused through barcode scan contains theory, learning video, and a Google Form as the student's worksheet. Aside from that, marker is used to displays the AR technology as 3D image animation. This teaching material book is generally composed of supporting component which are front cover, back cover, table of contents, user guide, bibliography and author profile and the main components which consist of learning objective and concept map, and 5 sub topic where each using syntax guided inquiry.

This research and development produce teaching materials with guided inquiry learning model, equipped with augmented reality, needs a feasibility test by doing validation. The validation was 
carried out by a lecturer from Science Education Major, Faculty of Mathematics and Natural Science, State University of Malang and a Science teacher from one of the middle school in Malang City. Quantitative data are numbers and the qualitative data are comments and suggestions. Assessment aspect for the quantitative data in the questionnaire for theory validation outlined in Table 1.

Tabel 1.

Percentage Results for Theory Validation of Teaching Material Analysis

\begin{tabular}{clcc}
\hline No & \multicolumn{1}{c}{ Assessed Aspects } & $\begin{array}{c}\text { Average Score } \\
\text { Percentage }\end{array}$ & Criteria \\
\hline 1 & Basic competencies and grammar & $100 \%$ & Very feasible \\
2 & The Nature of Light & $91 \%$ & Very feasible \\
3 & Image Formation by a Plane Mirror & $92 \%$ & Very feasible \\
4 & Image Formation by a Curved Mirror & $95 \%$ & Very feasible \\
5 & Image Formation by Lenses & $95 \%$ & Very feasible \\
6 & Human Sense of Sight & $92 \%$ & Very feasible \\
7 & Insects Sense of Sight & $88 \%$ & Very feasible \\
8 & Optics & $91 \%$ & Very feasible \\
\hline
\end{tabular}

The average percentage result for theory validation that had been carried out is $92 \%$ and it was in very feasible criteria. The test result for the correctivity of the concept/theory in the teaching material accorded with scoring criteria. The assessment aspect for the qualitative aspect in the questionnaire of media validation are outlined in Table 2.

Tabel 2.

Analytical Result Percentage of Validity of the Teaching Material's Media

\begin{tabular}{clcc}
\hline No & \multicolumn{1}{c}{ Assessed Aspects } & $\begin{array}{c}\text { Average Score } \\
\text { Percentage }\end{array}$ & Criteria \\
\hline 1 & Presentation Feasibility & $93 \%$ & Very feasible \\
2 & $\begin{array}{l}\text { Animation usage and Augmented } \\
\text { Reality (AR) }\end{array}$ & $94 \%$ & Very feasible \\
3 & Quiz questions & $95 \%$ & Very feasible \\
\hline
\end{tabular}


Average percentage for the validation result of the teaching material's media that has been done is $94 \%$ and it was in the very feasible criteria.

\section{Discussion}

\section{Research and Development Result Description}

The development result that has been done is a guided-inquiry based teaching material enriched by augmented reality (AR) in the subject of light and optics accorded with basic competencies 3.9 and $4.9 \mathrm{~K} 13$ 8th grade middle school. Teaching material layout was designed using Microsoft Publisher 2010 in A5 size (14,8 cm x $21 \mathrm{~cm})$. Guided-inquiry model is used because it can train experimental skill on the students to collect data and finding conceptual facts so the students are able to make a conclusion from processing those facts to solve the problem [10]. This teaching material book printed in A5 and combined with the augmented reality technology in apk extension. Augmented reality technology can increase the student's motivation to study in applying concepts in real environment and daily life from the newly gained perspective [11]. By using this AR technology, the teaching material is being able to produce a virtual object become more realistic so it can attract a higher curiosity for the students [12].

The developed teaching material consist of 5 sub topic, which are 1) the nature of light, 2) image formation by mirror and lenses, 3) human sense of sight, 4) insects sense of sight, and 5) optics. Each subtopic consist of 6 missions according to the strategy of guided-inquiry learning. Equipped with the exercises in the end of the general theory learning in the augmented reality application.

This teaching material is consist of the main and supporting component. The supporting component contains front cover, back cover, table of contents, user guide, bibliography and author profile. And the main components consist of learning objective and concept map, and the theories that are developed in guided-inquiry. Several advantages of this teaching material is including the theory in QR code that is linked to the Google Form, YouTube, and even a website address. Augmented reality presented in marker, which was then scanned to portray the image formation in mirror and lenses. Accessing this teaching material needs an internet connection since it's linked to the website address. The developed teaching material is used for a supporting book in the process of learning on 8th grade students.

Those specification aims to be put to a good use to the teaching material, inside or outside the classroom. Considering the current educational condition which still be held online due the Covid19 pandemic. The developed light and optics teaching material, is a side-kick to the main textbook in class. The advantage of this teaching material compared to the main textbook is there is a suitable learning model and equipped with the augmented reality technology. Guided inquiry 
learning model that had been used in the learning process can improve the concept understanding independently through the discovery process [10]. Guided inquiry put the teacher only as a facilitator in the learning activity so the students are guided to find the concept by themselves [6].

Augmented reality in teaching material displayed in the image formation by mirror and lenses which usually in the existing teaching material are portrayed only in a picture. It can attract the students interest to study because they've given the new stuff so that the students have the curiosity and can clarify the delivered theory by the previous teaching material. This is in accordance with the result that has been carried out by [11], that stated augmented reality could increase the motivation and attract the students interest in learning activity. Augmented reality also can improve the students learning achievements [13]. The display of the teaching material is showed in Figure 2.

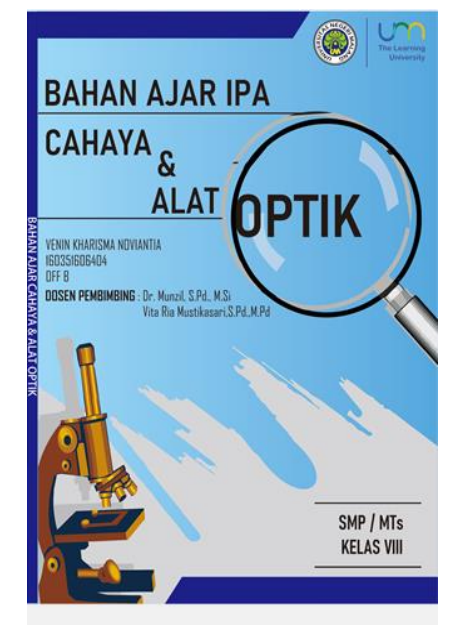

(a)

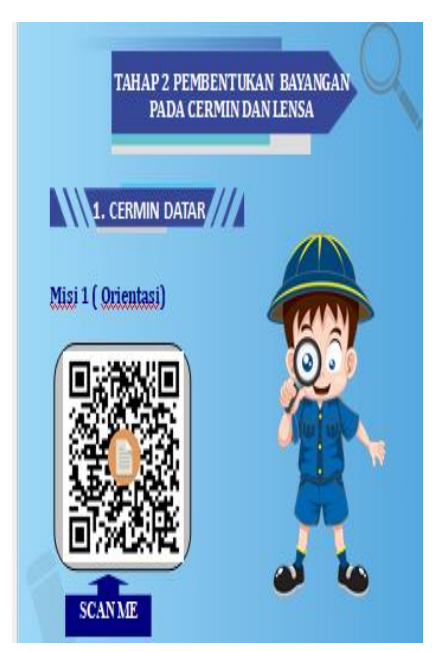

(b)

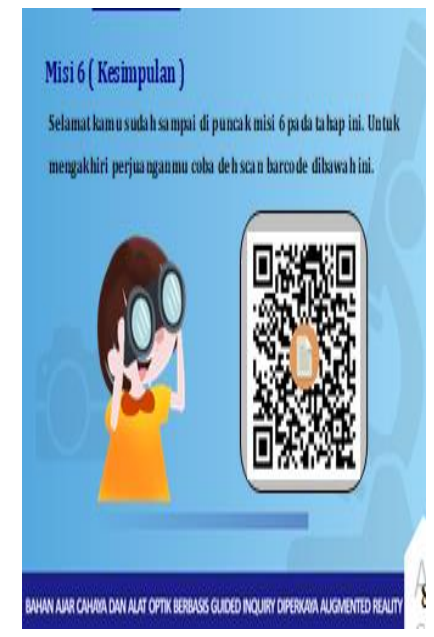

(c)

Figure 2. (a) Front Cover, (b) Orientation Content (c) Concluding Content

Based on the validation result from the expert validator, the teaching material with guidedinquiry model equipped with augmented reality in the subject of light and optics obtained overall percentage score of $93 \%$ with the very feasible criteria. There are two feasibility to the teaching material, including theoretical feasibility and media feasibility. Theoretical feasibility divided into 8 aspects. Aspect average percentage for basic competencies and grammar was $100 \%$ with very feasible criteria. For the nature of light aspect, it obtained 90,7\% with very feasible criteria. Aspect percentage score obtained for the image formation by plane mirror was $92 \%$ with very feasible criteria. Meanwhile the percentage score obtained for the image formation by curved mirror and lenses aspect got the same average percentage, which was $95.2 \%$ with very feasible criteria. Aspect percentage score in human sense of sight topic was $92 \%$ with very feasible criteria. Meanwhile insects sense of sight obtained $88 \%$ which was in very feasible criteria. The last aspect that assessed in the theoretical validation was optics which got $91 \%$ and it included in very feasible criteria. Finally percentage score for overall aspects was $92 \%$ in the very feasible category. For validity/feasibility of the concept, the validator stating that it was valid/true. 
Assessed aspects in the media validation questionnaire involve image display presentation, text, video, and augmented reality animation in each media component which are contained in the teaching material. Media in this teaching material consist of learning video in YouTube, accessed theory through the link in QR code and the marker which is used to scan augmented reality technology, and the quiz in the light and optics application. Presentation feasibility was in very feasible criteria by average score of $93.1 \%$. Meanwhile for the animation and augmented reality got $94.5 \%$ which was in very feasible criteria. Percentage of the last aspect assessed in media validation was $95.2 \%$ for the quiz, and it was in the very feasible criteria. Average score obtained for all aspects in media validation questionnaire was $94 \%$.

This teaching material also designed as a simple pocket book, easy to carry and make it easy to learn inside or outside the classroom during Covid-19 pandemic. Therefore, middle school student can keep up with the science learning online according to 2013 curriculum. The students can use this media without any teacher or fellow student necessary. Student can use it by following the learning stages that has been compiled inside the teaching material because it is equipped with sequence instructions, while the teacher can use this teaching material by keep explaining instructional purpose of the theory, and noticing and explaining guided-inquiry stages that the student having trouble to understand. The teacher can also measure student's level of understanding though the guided-inquiry stages.

\section{Conclusion}

This teaching material development produce a guided-inquiry based enriched by augmented reality in the subject of light and optics for 8th grade students. The average result for theoretical validation was $92 \%$ and media validation was $94 \%$. Based on those results, the learning material was valid and feaseble to use in the learning activity in both schools and home during the Covid19 pandemic era.

\section{Acknowledgment}

The authors would like to express their gratitude to Universitas Negeri Malang for providing research grantunder the scheme of PNBP UM 2020.

\section{References}

[1] Lestari, W. (2012). Pengembangan Perangkat Pembelajaran Ipa Smp Berbasis Kooperatif Tipe Stad Pada Tema Fotosintesis Di Smp Giki-3 Surabaya. Pensa: Jurnal Pendidikan Sains, $1(01), 1-8$.

[2] Nurkhasanah, I., Prihandono, T., \& Supriadi, B. (2016). Pengaruh Model Inkuiri Terbimbing (Guided Inquiry) Disertai Metode Mencongak Terhadap Hasil Belajar Siswa Pada 
Pembelajaran Ipa (Fisika) Kelas Vii Di Smp Al-Maliki Sukodono - Lumajang. Jurnal Pembelajaran Fisika Universitas Jember, 5(1), 66-67.

[3] Sutopo. (2014). Miskonsepsi pada Optika Geometri dan Remidiasinya. J-Teqip, V(2), 356368.

[4] Fatimah, S., Suryandari, C., \& Triyono. (2014). Penerapan Paikem Model Quantum Teaching dalam Peningkatan Pembelajaran IPA kelas V Sekolah Dasar. The Hokuriku Crop Science, 3, 1-3. https://doi.org/10.19016/jcshokuriku.3.0_1

[5] Lestari, N. I., Sutopo, \& Pratiwi, N. (2018). Pembelajaran dengan pemodelan pada materi cahaya dan alat optik untuk meningkatkan penguasaan konsep siswa kelas viii [*].

[6] Prihatin, P., Prayitno, B. A., \& Rinanto, Y. (2017). Pengembangan modul berbasis inkuiri terbimbing pada materi jamur untuk meningkatkan kemampuan berpikir kritis siswa kelas $\mathrm{X}$ SMA Negeri 1 Cepogo Boyolali. Jurnal Inkuiri, 6(1), 75-90. https://doi.org/10.20961/inkuiri.v6i1.17268

[7] Ivanova, M., \& Ivanov, G. (2011). Enhancement of Learning and Teaching in Computer Graphics Through Marker Augmented Reality Technology. International Journal of New Computer Architectures and Their Applications (IJNCAA), 1(1), 176-184.

[8] Kemendikbud. Surat Edaran Nomor 4 Tahun 2020. 2020;300.

[9] W.Lee, W., \& Owens, D. L. (2004). Multimedia-Based Intructional Design (2nd ed.; M. Davis, ed.). San Francisco: Pfeiffer.

[10] Iman, R., Khaldun, I., \& Nasrullah. (2017). Meningkatkan Kemampuan Berpikir Kritis Siswa Dengan Model Inkuiri Terbimbing Pada Materi Pesawat Sederhana. Jurnal Pendidikan Sains Indonesia (Indonesian Journal of Science Education), 5(1), 52-58.

[11] Pratama, G. Y. (2018). Analisis Penggunaan Media Augmented Reality Sebagai Media Pembelajaran Terhadap Motivasi.

[12] Bujak, K. R., Radu, I., Catrambone, R., MacIntyre, B., Zheng, R., \& Golubski, G. 2013. A psychological perspective on augmented reality in the mathematics classroom. Computers and Education, 68, 536-544. https://doi.org/10.1016/j.compedu.2013.02.017

[13] Akçayır, M., \& Akçayır, G. 2017. Advantages and challenges associated with augmented reality for education: A systematic review of the literature. Educational Research Review, 20, 1-11. https://doi.org/10.1016/j.edurev.2016.11.002 